\title{
ANALISIS FAKTOR YANG BERHUBUNGAN DENGAN PERILAKU JAJAN PADA ANAK SEKOLAH DASAR DI SD NEGERI CIKUNIR KECAMATAN SINGAPARNA KABUPATEN TASIKMALAYA TAHUN 2015 OLEH : Sinta Fitriani, S.KM,M.KM
}

\section{A. ABSTRAK}

Hasil penelitian Badan Pengawas Obat dan Makanan (Badan POM) tahun 2012 mengungkapkan bahwa sebanyak 76\% pangan jajanan anak sekolah (PJAS) di Indonesia telah memenuhi persyaratan keamanan, ini menunjukan masih ada 24 $\%$ yang belum memenuhi syarat, berdasarkan hasil pemeriksaan laboratorium pada 68 sampel yang diperiksa, ditemukan $18 \%$ sampel mengandung bahan kimia berbahaya(Sumber, Dinas Kesehatan, 2014). Berdasarkan hasil observasi awal di SD Negeri Cikunir didapatkan bahwa SDN Cikunir tidak memiliki kantin di sekolah. Hanya terdapat penjaja jajanan anak sekolah di luar sekolah. Perilaku jajan pada anak sekolah yang sangat tinggi, serta kebersihan jajanan yang kurang (terdapat beberapa penyaji jajanan terbuka) serta hampir semua penyaji makanan menggunakan bahan makanan tambahan seperti bumbu penyedap, saus dan lain lain. Tujuan dari penelitian ini adalah mengetahui faktor faktor yang berhubungan dengan perilaku jajan pada anak sekolah SD Negeri Cikunir Kecamatan Singaparna Kabupaten Tasikmalaya Tahun 2015.

Jenis penelitian yang digunakan adalah kuantitatif dengan metode deskriptif.Populasi dalam penelitian ini adalah seluruh siswa siswi SD Negeri Cikunir kelas 1 - 3 yaitu 86 orang. Variabel dalam penelitian ini adalah pengetahuan, sikap, kebiasaan membawa bekal dari rumah, peran guru serta perilaku jajan. Instrumen dalam penelitian ini menggunakan kuesioner. Analisis data dalam penelitian ini adalah analisis univariat dan bivariat. Sedangkan analisis bivariat untuk mengetahui hubungan antara variabel bebas (pengetahuan, sikap, kebiasaan membawa bekal serta dukungan guru) dengan variabel terikat (perilaku jajan). Uji analisis data yang digunakan adalah chisquare .

Hasil penelitian didapatkan Mayoritas pengetahuan siswa tentang jajanan anak termasuk kategori kurang yaitu 68 orang (79,1\%). sikap siswa SDN Cikunir tentang jajanan adalah tidak mendukung atau sikap negatif yaitu 64 orang (74,4\%), 59 orang $(68,6 \%)$ tidak memiliki kebiasaan membawa bekal makanan dari rumah ke sekolah serta siswa (53,5\%) menyatakan mendapat dukungan dari guru berupa pemberian informasi dan larangan bahaya jajan sembarangan. Hasil uji statistik didapatkan variabel pengetahuan $(P=0,001)$, sikap $(P=0,004)$, kebiasaan membawa bekal $(P=0,000)$ berhubungan dengan perilaku jajan sedangkan dukungan guru tidak berhubungan dengan perilaku jajan $(P=0,071)$.

Diharapkan dapat merancang kegiatan pencegahan resiko jajanan anak sekolah melalui pemberian informasi tentang bahaya jajanan anak sekolah serta perancangan aturan pengaturan dan pembinaan pedagang di sekitar sekolah.

Kata kunci : Perilaku jajan, anak sekolah, pengetahuan, sikap, kebiasan membawa bekal dan dukungan guru 


\section{B. PENDAHULUAN}

Salah satu permasalahan pada anak usia sekolah adalah perilaku jajan yang tidak sehat, makanan jajanan adalah makanan dan atau minuman yang diolah oleh pengrajin makanan di tempat penjualan dan atau disajikan sebagai makanan siap santap untuk dijual bagi umum (Permenkes no. 236,1997). Jajanan di sekolah harus mendapat perhatian dari pihak sekolah dalam rangka menjaga kesehatan siswa dari bahaya yang terdapat dalam jajanan sekolah sehingga perlu pengawasan secara komprehensif bersama Dinas Kesehatan dan Dinas Perindustrian dan Perdagangan.

Hasil penelitian Badan Pengawas Obat dan Makanan (Badan POM) tahun 2012 mengungkapkan bahwa sebanyak $76 \%$ pangan jajanan anak sekolah (PJAS) di Indonesia telah memenuhi persyaratan keamanan, ini menunjukan masih ada $24 \%$ yang belum memenuhi syarat, berdasarkan hasil pemeriksaan laboratorium pada 68 sampel yang diperiksa, ditemukan $18 \%$ sampel mengandung bahan kimia berbahaya(Sumber, Dinas Kesehatan, 2014), oleh karena itu diperlukan pemberian pemahaman yang baik kepada siswa akan bahayanya makanan jajanan tersebut.

Berdasarkan hasil observasi awal di SD Negeri Cikunir didapatkan bahwa SDN Cikunir tidak memiliki kantin di sekolah. Hanya terdapat penjaja jajanan anak sekolah di luar sekolah. Perilaku jajan pada anak sekolah yang sangat tinggi, serta kebersihan jajanan yang kurang (terdapat beberapa penyaji jajanan terbuka) serta hampir semua penyaji makanan menggunakan bahan makanan tambahan seperti bumbu penyedap, saus dan lain lain. (Laporan kegiatan abdimas tahun 2015)

Beberapa faktor yang mempengaruhi perilaku jajan pada anak sekolah diantaranya pengetahuan, sikap, ketersediaan jajanan, biaya/bekal siswa serta peran guru di sekolah. Faktor-faktor ini baik yang mempermudah, pemungkin maupun penguat semuanya sangat berperan penting dalam perubahan perilaku jajan anak sekolah sehingga perlu pembinaan dan pengawasan dari semua pihak terutama pihak sekolah sehingga dapat mengurangi resiko dari bahaya jajanan sekolah. ( Fitriani, 2011)

Tujuan dari penelitian ini adalah mengetahui faktor faktor yang berhubungan dengan perilaku jajan pada anak sekolah SD Negeri Cikunir Kecamatan Singaparna Kabupaten Tasikmalaya Tahun 2015.

\section{METODOLOGI PENELITI}

1. Jenis penelitian Jenis penelitian yang digunakan adalah kuantitatif dengan metode deskriptif.

2. Populasi dan sampel

Populasi dalam penelitian ini adalah seluruh siswa siswi SD Negeri Cikunir kelas $1-3$ yaitu 86 orang. Tehnik pengambilan sampel yang digunakan adalah total sampling dimana seluruh populasi dijadikan sampel dalam penelitian ini.

3. Waktu dan tempat penelitian

Waktu penelitian adalah bulan November - Desember 2015

Tempat penelitian : SD Negeri Cikunir

4. Variabel

Variabel dalam penelitian ini adalah pengetahuan, sikap, kebiasaan membawa bekal dari rumah, peran guru serta perilaku jajan

5. Instrumen penelitian

Instrumen dalam penelitian ini menggunakan kuesioner. Untuk Variabel pengetahuan 10 soal, sikap 8 soal, bekal 1 soal, peran guru 1 soal serta 1 soal untuk mengukur perilaku jajan.

6. Pengolahan data

Pengolahan data penelitian dilakukan dengan cara :

\section{a. Editing}

Tahapan ini dilakukan dengan cara mengecek kelengkapan kebutuhan data penelitian.

b. Coding

Pemberian kode untuk setiap pilihan jawaban seperti : 
1. Untuk variabel pengetahuan kode 1 untuk pengetahuan baik dan kode 2 untuk kurang

2. Untuk variabel sikap; kode 1 mendukung dan kode 2 tidak mendukung

3. Untuk variabel kebiasaan membawa bekal; kode 1 ya dan kode 2 tidak

4. Untuk variabel dukungan guru; kode 1 mendukung dan kode 2 tidak mendukung

5. Untuk variabel perilaku jajan ; kode 1 jarang dan kode 2 sering

\section{c. Entry data}

Proses memasukan data ke program komputerisasi untuk disajikan dalam bentuk tabel dan dianalisis secara narasi

7. Analisis data

Analisis data dalam penelitian ini adalah analisis univariat dan bivariat. Analisis univariat menghasilkan distribusi frekuensi untuk menggambarkan tiap- tiap variabel yang akan diteliti. Sedangkan analisis bivariat untuk mengetahui hubungan antara variabel bebas (pengetahuan, sikap, kebiasaan membawa bekal serta dukungan guru) dengan variabel terikat (perilaku jajan). Uji analisis data yang digunakan adalah chisquare dimana apabila $\mathrm{p}$ value $>$ dari 0,05 maka dinyatakan ada hubungan.

\section{HASIL PENELITIAN}

1. Pengetahuan siswa dan perilaku jajan

Tabel 4.1

Distribusi Frekwensi pengetahuan siswa tentang jajanan di SD N Cikunir Kecamatan Singaparna Kabupaten Tasikmalaya

\begin{tabular}{|r|c|c|c|}
\hline No & Pengetahuan & F & \% \\
\hline 1 & Baik & 18 & 20,9 \\
\hline 2 & Kurang & 68 & 79,1 \\
\hline & & & \\
\hline & Jumlah & $\mathbf{8 6}$ & $\mathbf{1 0 0}$ \\
\hline
\end{tabular}

Berdasarkan tabel 4.1 didapatkan bahwa mayoritas pengetahuan siswa tentang jajanan anak sekolah di SD N Cikunir adalah termasuk kategori kurang yaitu 68 orang atau 79,1\%. 
Tabel 4.2

Tabulasi silang anatara pengetahuan siswa dengan perilaku jajan di SD N Cikunir Kecamatan Singaparna Kabupaten Tasikmalaya

\begin{tabular}{|l|r|r|r|r|r|r|r|}
\hline $\begin{array}{l}\text { Perilaku } \\
\text { jajan }\end{array}$ & \multicolumn{5}{|c|}{ Pengetahuan } & $\begin{array}{c}\text { P } \\
\text { VALUE }\end{array}$ \\
\hline Jarang & Baik & \% & Kurang & \% & Jumlah & \% & \\
\hline Sering & 13 & 72,2 & 5 & 27,8 & 18 & 100 & 0,001 \\
\hline JUMLAH & $\mathbf{3 1}$ & 26,5 & 50 & 73,5 & 68 & 100 & \\
\hline
\end{tabular}

Berdasarkan data diatas dinyatakan bahwa hasil analisis hubungan antara pengetahuan dan perilaku jajan pada siswa diperoleh 50 (73,5\%) siswa yang pengetahuannya kurang berperilaku jajan sering. Sedangkan 5 orang $(27,8 \%)$ siswa yang pengetahuan kurang termasuk kategori perilaku jajan yang jarang. Hasil uji statistik didapatkan bahwa nilai $P=0,001$ maka dapat disimpulkan bahwa terdapat hubungan yang signifikan antara pengetahuan siswa dengan perilaku jajan.

2. Sikap siswa dan perilaku jajan

Tabel 4.3

Distribusi Frekwensi sikap siswa tentang jajanan di SD N Cikunir Kecamatan Singaparna Kabupaten Tasikmalaya

\begin{tabular}{|l|l|c|c|}
\hline No & \multicolumn{1}{|c|}{ Sikap } & F & \% \\
\hline 1 & Mendukung & 22 & 25,6 \\
\hline 2 & Tidak mendukung & 64 & 74,4 \\
\hline & & & \\
\hline & Jumlah & $\mathbf{8 6}$ & $\mathbf{1 0 0}$ \\
\hline
\end{tabular}

Berdasarkan tabel 4.2 didapatkan bahwa mayoritas sikap siswa SDN Cikunir tentang jajanan adalah tidak mendukung atau sikap negatif yaitu 64 orang $(74,4 \%)$

Tabel 4.4

Tabulasi silang antara sikap siswa dengan perilaku jajan di SD N Cikunir Kecamatan Singaparna Kabupaten Tasikmalaya

\begin{tabular}{|c|c|c|c|c|c|c|c|}
\hline $\begin{array}{c}\text { Perilaku } \\
\text { jajan }\end{array}$ & \multicolumn{5}{|c|}{ Sikap } & $\begin{array}{c}\text { P } \\
\text { VALUE }\end{array}$ \\
\hline & Mendukung & $\%$ & $\begin{array}{c}\text { Tidak } \\
\text { menduk } \\
\text { ung }\end{array}$ & $\%$ & Jumlah & $\%$ & \\
\hline Jarang & 14 & 63,6 & 8 & 36,4 & 22 & 100 & 0,04 \\
\hline Sering & 17 & 26,6 & 47 & 73,4 & 64 & 100 & \\
\hline JUMLAH & $\mathbf{3 1}$ & $\mathbf{3 6 , 0}$ & $\mathbf{5 5}$ & $\mathbf{6 4}$ & $\mathbf{8 6}$ & $\mathbf{1 0 0}$ & \\
\hline
\end{tabular}


Berdasarkan data diatas dinyatakan bahwa hasil analisis hubungan antara sikap dan perilaku jajan pada siswa diperoleh $14(63,6 \%)$ siswa yang bersikap mendukung (positif) termasuk kategori jarang jajan sedangkan $17(26,6 \%)$ siswa yang memiliki sikap mendukung (positif ) termasuk kategori sering jajan.. Hasil uji statistik didapatkan bahwa nilai $\mathrm{P}=0,004$ maka dapat disimpulkan bahwa terdapat hubungan yang signifikan antara sikap siswa dengan perilaku jajan.

\section{Kebiasaan membawa bekal dan perilaku jajan}

4.

\section{Tabel 4.5}

Distribusi Frekwensi kebiasaan membawa bekal di SD N Cikunir Kecamatan Singaparna Kabupaten Tasikmalaya

\begin{tabular}{|l|c|c|c|}
\hline No & Kebiasaan membawa bekal & F & \% \\
\hline 1 & Ya & 27 & 31,4 \\
\hline 2 & Tidak & 59 & 68,6 \\
\hline & & & $\mathbf{1 0 0}$ \\
\hline & Jumlah & $\mathbf{8 6}$ & \\
\hline
\end{tabular}

Berdasarkan tabel 4.3 didapatkan bahwa mayoritas siswa di SD N Cikunir 59 orang $(68,6 \%)$ tidak memiliki kebiasaan membawa bekal makanan dari rumah ke sekolah.

Tabel 4.4

Tabulasi silang antara kebiasaan membawa bekal siswa dengan perilaku jajan di SD $\mathbf{N}$ Cikunir Kecamatan Singaparna Kabupaten Tasikmalaya

\begin{tabular}{|l|c|c|c|c|c|c|c|}
\hline \multicolumn{1}{|c|}{$\begin{array}{c}\text { Perilaku } \\
\text { jajan }\end{array}$} & \multicolumn{6}{|c|}{ Kebiasaaan membawa bekal } & P VALUE \\
\hline & Ya & \% & Tidak & \% & Jumlah & \% & \\
\hline Jarang & 20 & 74,1 & 7 & $\begin{array}{c}25, \\
9\end{array}$ & 27 & 100 & $\mathbf{0 , 0 0 0}$ \\
\hline Sering & 11 & 18,6 & 48 & $\begin{array}{c}81, \\
4\end{array}$ & 59 & 100 & \\
\hline JUMLAH & $\mathbf{3 1}$ & $\mathbf{3 6 , 0}$ & $\mathbf{5 5}$ & $\mathbf{6 4}$ & $\mathbf{8 6}$ & $\mathbf{1 0 0}$ & \\
\hline
\end{tabular}

Berdasarkan data diatas dinyatakan bahwa hasil analisis hubungan antara kebiasaan membawa bekal dengan perilaku jajan adalah siswa yang memiliki kebiasaan membawa bekal $74,1 \%$ jarang jajan sedangkan $18,6 \%$ siswa yang membawa bekal termasuk kategori sering jajan.. Hasil uji statistik didapatkan bahwa nilai $\mathrm{P}=0,000$ maka dapat disimpulkan bahwa terdapat hubungan yang signifikan antara kebiasaaan membawa bekal dengan perilaku jajan. 


\section{Dukungan guru dan perilaku jajan}

Tabel 4.7

Distribusi Frekwensi dukungan di SD N Cikunir Kecmatan Singaparna Kabupaten Tasikmalaya

\begin{tabular}{|c|c|c|c|}
\hline No & Dukungan guru & F & \% \\
\hline 1 & Ya & 46 & 53,5 \\
\hline 2 & Tidak & 40 & 46,5 \\
\hline & & & \\
\hline & Jumlah & $\mathbf{8 6}$ & $\mathbf{1 0 0}$ \\
\hline
\end{tabular}

Berdasarkan tabel 4.1 didapatkan bahwa mayoritas siswa (53,5\%) menyatakan mendapat dukungan dari guru berupa pemberian informasi dan larangan bahaya jajan sembarangan

Tabel 4.8

Tabulasi silang antara dukungan guru dengan perilaku jajan di SD N Cikunir Kecamatan Singaparna Kabupaten Tasikmalaya

\begin{tabular}{|c|c|c|c|c|c|c|c|}
\hline Perilaku & \multicolumn{6}{|c|}{ Dukungan guru } & \multirow[t]{2}{*}{ P VALUE } \\
\hline & Ya & $\%$ & Tidak & $\%$ & Jumlah & $\%$ & \\
\hline Jarang & 21 & 45,7 & 25 & 54,3 & 46 & 100 & 0,071 \\
\hline Sering & 10 & 25 & 30 & 75 & 40 & 100 & \\
\hline JUMLAH & 31 & 36,0 & 55 & 64,0 & 86 & 100 & \\
\hline
\end{tabular}

Berdasarkan data diatas dinyatakan bahwa hasil analisis hubungan antara dukungan guru dengan perilaku jajan adalah siswa yang mendapatkan dukungan positif dari guru 45,7\% jarang berperilaku Jajan sedangkan 25\% siswa yang mendapatkan dukungan dari guru termasuk kategori sering jajan. Hasil uji statistik didapatkan bahwa nilai $\mathrm{P}=0,071$ maka dapat disimpulkan bahwa tidak terdapat hubungan antara kebiasaaan dukungan guru dengan perilaku jajan. 
6. Perilaku jajan siswa

Tabel 4.9

Distribusi Frekwensi perilaku jajan pada siswa SD N Cikunir Kecmatan Singaparna Kabupaten Tasikmalaya

\begin{tabular}{|c|c|c|c|}
\hline No & Perilaku jajan & F & \% \\
\hline 1 & Jarang (1 kali) & 31 & 36,0 \\
\hline 2 & Sering (lebih dari 1 kali sehari) & 55 & 64,0 \\
\hline & & & \\
\hline & Jumlah & $\mathbf{8 6}$ & $\mathbf{1 0 0}$ \\
\hline
\end{tabular}

Berdasarkan tabel 4.1 didapatkan bahwa mayoritas siswa $(64,0 \%)$ berperilaku jajan sering (lebih dari 1 kali dalam sehari.

\section{E. PEMBAHASAN}

\section{Pengetahuan dan perilaku jajan}

Berdasarkan hasil penelitian didapatkan bahwa mayoritas pengetahuan siswa tentang jajanan anak sekolah di SD $\mathrm{N}$ Cikunir adalah termasuk kategori kurang yaitu 68 orang $(79,1 \%)$.

Sedangkan hasil analisis hubungan antara pengetahuan dan perilaku jajan pada siswa diperoleh $50(73,5 \%)$ siswa yang pengetahuannya kurang berperilaku jajan sering. Sedangkan 5 orang $(27,8 \%)$ siswa yang pengetahuan kurang termasuk kategori perilaku jajan yang jarang. Hasil uji statistik didapatkan bahwa nilai $\mathrm{P}=$ 0,001 maka dapat disimpulkan bahwa terdapat hubungan yang signifikan antara pengetahuan siswa dengan perilaku jajan.

Hal ini sesuai dengan teori yang menyatakan bahwa pengetahuan merupakan hasil dari "tahu" dan ini terjadi setelah orang melakukan penginderaan terhadap objek tertentu. Penginderaan terjadi melalui panca indera manusia, yakni indera penglihatan, pendengaran, penciuman, rasa dan raba. Sebagian besar, pengetahuan manusia diperoleh dari mata dan telinga (Notoatmodjo, 2011)

$$
\text { Salah satu faktor yang }
$$

berhubunngan dengan perilaku jajan adalah pengetahuan siswa tentang bahaya jajanan anak sekolah yang kurang. Semakin baik pengetahuan siswa maka akan berpengaruh terhadap perilaku jajan pada siswa tersebut. Pengetahauan tentang baik buruknya dampak jajanan terhadap kesehatan menjadi salah satu faktor yang dipertimbangkan sebelum jajan.

Pengetahuan merupakan hasil dari "tahu" dan ini terjadi setelah orang melakukan penginderaan terhadap obyek tertentu. Penginderaan terjadi melalui panca indra manusia, yakni indera penglihatan, pendengaran, penciuman, rasa dan raba. Sebagian besar, pengetahuan manusia diperoleh dari mata dan telinga. Pengetahuan seseorang tentang suatu obyek mengandung dua aspek yaitu aspek positif dan aspek negative yang keduanya menentukan sikap seseorang (Wawan \& Dewi, 2011).

Pengetahuan mengenai makanan jajanan adalah kepandaian memilih makanan yang merupakan sumber zat-zat gizi dan kepandaian dalam memilih makanan jajanan yang sehat. Pengetahuan gizi anak sangat berpengaruh terhadap pemilihan makanan jajanan. Pengetahuan anak dapat diperoleh baik secara internal maupun eksternal. Pengetahuan secara internal yaitu pengetahuan yang berasal dari dirinya sendiri berdasarkan pengalaman hidup. Pengetahuan secara eksternal yaitu pengetahuan yang berasal dari orang lain sehingga pengetahuan anak tentang gizi bertambah (Solihin, 2005). 
Rendahnya pengetahuan siswa tentang jajanan anak sekolah turut memberi peran dalam perilaku jajan pada anak sekolah. Hal ini sesuai dengan penelitian Sudarmawan di SDN Sambikerep II/480 Surabaya bulan November tahun 2012, disimpulkan bahwa terdapat hubungan pengetahuan dengan perilaku anak memilih jajanan dengan nilai signifikan $0,027((p<0,05)$

Dibutuhkan upaya yang lebih intensif dalam meningkatkan pengetahuan siswa melalui kegiatan penyuluhan ke sekolah. Keterlibatan guru dalam menyampaikan informasi terkait bahaya jajajan anak sekolah turut memiliki peran dalam menambah pengetahuan siswa. Selain itu intervensi petugas kesehatan dalam program penyuluhan tentang bahaya jajanan anak sekolah diharapkan mampu meningkatkan pengetahuan dan wawasan siswa sehingga berpengaruh terhadap perilaku jajan anak sekolah.

\section{Sikap dan perilaku jajan}

Berdasarkan hasil penelitian didapatkan bahwa mayoritas sikap siswa SDN Cikunir tentang jajanan adalah tidak mendukung atau sikap negatif yaitu 64 orang $(74,4 \%)$. Sedangkan hasil analisis hubungan antara sikap dan perilaku jajan pada siswa diperoleh $14(63,6 \%)$ siswa yang bersikap mendukung (positif) termasuk kategori jarang jajan sedangkan $17(26,6 \%)$ siswa yang memiliki sikap mendukung (positif ) termasuk kategori sering jajan.. Hasil uji statistik didapatkan bahwa nilai $\mathrm{P}=0,004$ maka dapat disimpulkan bahwa terdapat hubungan yang signifikan antara sikap siswa dengan perilaku jajan.

Hal ini sesuai dengan teori yang menyatakan Sikap menurut Notoatmodjo (2003) adalah merupakan reaksi atau respon seseorang yang masih tertutup terhadap suatu stimulus atau objek. Sikap menurut Sunaryo (2004) adalah kecenderungan bertindak dari individu, berupa respon tertutup terhadap stimulus ataupun objek tertentu. Jadi, sikap merupakan reaksi atau respon yang masih tertutup dari seseorang terhadap suatu stimulus atau objek.

Sikap belum merupakan suatu tindakan atau aktivitas, akan tetapi merupakan predisposisi tindakan suatu perilaku. Sikap merupakan kesiapan untuk bereaksi terhadap objek dilingkungan tertentu sebagai suatu penghayatan terhadap objek. Sikap siswa yang positif terhadap bahaya jajanan anak sekolah turut berpengaruh terhadap perilaku jajan anak sekolah. Sikap adalah respons terhadap stimuli sosial yang telah terkondisikan (LaPierre, 1934 dalam Azwar, 2011).

Sikap merupakan salah satu faktor yang mempermudah terjadinya perilaku jajan anak sekolah Tingginya sikap negatif tentang perilaku jajan turut berperan dalam perilaku jajan anak sekolah. hal ini sesuai dengan hasil penelitian yang dilakukan oleh Safriana di SDN Garot Kecamatan Darul Imarah Kabupaten Aceh Besar NAD tahun 2012, dari 69 siswa yang berperilaku tidak baik dalam memilih jajanan sekolah, 38 orang (67\%) memiliki sikap tidak mendukung, sehingga dapat di simpulkan bahwa sikap sangat berpengaruh pada perilaku jajan anak sekolah.

Selain pengetahuan yang baik tentang resiko jajan sembarangan pada anak sekolah dibutuhkan upaya menanamkan keyakinan sehingga mampu membentuk persepsi baik tentang perilaku jajan dapat berperan membentuk sikap yang positif mendukung terhadap ketidak setujuan berperilaku jajan sembarangan.

\section{Kebiasaan membawa bekal dan perilaku jajan}

Berdasarkan hasil penelitian didapatkan bahwa mayoritas siswa di SD $\mathrm{N}$ Cikunir 59 orang $(68,6 \%)$ tidak memiliki kebiasaan membawa bekal makanan dari rumah ke sekolah. Sedangkan hasil analisis hubungan antara kebiasaan membawa bekal dengan 
perilaku jajan adalah siswa yang memiliki kebiasaan membawa bekal $74,1 \%$ jarang jajan sedangkan $18,6 \%$ siswa yang membawa bekal termasuk kategori sering jajan.. Hasil uji statistik didapatkan bahwa nilai $\mathrm{P}=0,000$ maka dapat disimpulkan bahwa terdapat hubungan yang signifikan antara kebiasaaan membawa bekal dengan perilaku jajan.

Hal ini sesuai dengan teori yang menyatakan bahwa makanan bekal juga dapat menjadi tambahan makan pagi anak. Makanan tambahan ini dibutuhkan sebab kebutuhan gizi anak semakin meningkat sedangkan kemampuan saluran cerna untuk mengkonsumsi masih terbatas, sehingga diperlukan bekal makanan. Lama waktu sekolah (56 jam) atau bertambahnya kegiatan siswa di luar sekolah bisa pula menyebabkan anak membutuhkan tambahan makanan.

Bekal sekolah merupakan faktor pemungkin yang mempengaruhiperilaku jajan anak sekolah, bekal sekolah adalah uang yang diberikan orang tua kepada anaknya untuk membeli makanan dan minuman selama berada di sekolah ,sehingga dengan tersedianya uang jajan tersebut anak sekolah mempunyai kemampuan untuk jajan di sekolah.

Berdasarkan hasil penelitian yang dilakukan oleh Andika Eka Putra di Sekolah Dasar Hj. Isriati Semarang, diperoleh hasil bahwadari 78 orang sampel yang diteliti, $91 \%$ (71 orang) jajan di sekolah karena adanya uang jajan yang diberikan oleh orang tuanya, sehinggadapat disimpulkan bahwa uang jajan sangat berpengaruh pada perilaku jajan anak sekolah.

Selain itu, maraknya penggunaan zat kimia berbahaya dalam makanan jajanan, seperti pewarna, penyedap rasa, hingga pengawet perlu diwaspadai. Salah satu cara agar anak terhindar dari makanan jajanan yang tidak sehat adalah membekali anak dengan makanan bekal.

Penelitian di Jakarta tahhun 2013 menyebutkan sekitar 5\% anak membawa bekal makan. Sedangkan pada penelitian Andika di SD $\mathrm{Hj}$ IsratiSemarang tahun 2009 didapatkan , sebanyak 30 responden $(38,5 \%)$ membawa bekal makanan ke sekolah.

Untuk itu dalam upaya pencegahan perilaku jajan sembarangan sebaiknya orang tua perlu mempertimbangkan untuk menerapkan Kebiasaan membawa bekal sebagai salah satu upaya pemenuhan kebutuhan gizi anak sekolah serta mencegah perilaku jajan sembarangan.

\section{Dukungan guru dan perilaku jajan}

Berdasarkan hasil penelitian didapatkan bahwa mayoritas siswa $(53,5 \%)$ menyatakan mendapat dukungan dari guru berupa pemberian informasi dan larangan bahaya jajan sembarangan. Sedangkan hasil analisis hubungan antara dukungan guru dengan perilaku jajan adalah siswa yang mendapatkan dukungan positif dari guru $45,7 \%$ jarang berperilaku Jajan sedangkan $25 \%$ siswa yang mendapatkan dukungan dari guru termasuk kategori sering jajan. Hasil uji statistik didapatkan bahwa nilai $\mathrm{P}=0,071$ maka dapat disimpulkan bahwa tidak terdapat hubungan antara kebiasaaan dukungan guru dengan perilaku jajan.

Guru memiliki peran yang sangat besar di sekolah. Sebagai role model perilaku, guru juga dapat menjadi sosok yang berpengaruh terutama dalam memberikan informasi tentang bahaya jajanan anak sekolah, penerapan sanksi atau larangan jajan sembarangan.

Akan tetapi dalam penelitian ini tidak sesuai dengan teori, dimana peran guru terhadap perilaku jajan pada anak sekolah dirasakan kurang berpengaruh. Faktor lain seperti ketidak tersediaan kantin sehat di sekolah sepertinya salah satu faktor yang turut mendukung perilaku jajan pada anak sekolah. 
Pemberian informasi tentang bahaya jajanan anak sekolah sebaiknya dilakukan secara reguler dan berkesinambungan. Selain itu pihak sekolah diharapkan dapat merancang program maupun aturan baik itu larangan maupun himbauan terkait resiko jajanan anak sekolah. Intervensi ini tidak hanya pada siswa anak sekolah tetapi juga pada para pedagang yang berjualan di sekitar sekolah.

Faktor penguat merupakan faktor-faktor yang mendorong atau memperkuat terjadinya perilaku seperti tokoh masyarakat (toma), tokoh agama (toga), keluarga, teman, guru dan petugas kesehatan. Faktor peranan guru merupakan faktor yang dominan di sekolah, guru sebagai pendidik, pengawas sekaligus berperan sebagai orang tua di sekolah dapat melakukan pengawasan di area sekolah serta berkoordinasi dengan pihak Kesehatan, sehingga pengawasan dan bimbingan guru terhadap siswa sangat berperan dalam perilaku jajan anak sekolah.

Berdasarkan hasil penelitian yang dilakukan oleh Rina Nuzulia Fitripada Tahun 2007 di Kota Bogor, diketahui bahwa perilaku jajan anak sekolah dipengaruhi oleh peran guru dimana ada penyuluhan yang disampaikan oleh guru berdasarkan pengetahuan dan persepsinya tentangjajanan sekolah, dimana jajanan di sekitar sekolah aman untuk dikonsumsi $(69,38 \%)$, sedangkan jajanan di luar sekolah kurang bersih (85 $\%$ ). Hal ini dapat didisimpulkan bahwa perilaku jajan anak sekolah dapat dipengaruhi oleh peran guru dalam hal pemilihan jajanan di sekitar sekolah dan luar sekolah.

Salah satu kegiatan UKS adalah pelayanan kesehatan yangtermasuk di dalamnya pembinaan warung sekolah yang kegiatannya membina lingkungan sehat sekolah yang meliputi penyediaan kantin sekolah yang sehat serta penataan dan pembinaan pangan jajanan di luar lingkungan sekolah. Guru merupakan anggota tim pelaksana UKS yang yangmempunyai tugas dan peranan yang salah satunya adalahmelaksanakan pendidikan kesehatan, pelayanan kesehatan dan pembinaan lingkungan sekolah yang sehat termasuk didalamnya pengawasan terhadap kantin sekolah beserta tempat jajanan diluar sekolah, pengawasan pangan jajanan di luar lingkungan sekolah dan bekerjasama dengan orang tua murid dalam pengawasan dan pembinaan perilaku jajan siswa di sekolah (Ditjen PP \& PL Kemenkes RI, 2013). Selain itu dalam rangka pemantauan dan evaluasi perilaku hidup bersih dan sehat di sekolah, guru mempunyai tugas :

(a) Mengamati dimana siswa membeli makanan selama di sekolah,dan dipastikan siswa mengkonsumsi makanan dari kantin atau tempat jual makanan yang sehat sehingga siswa terhindar dari resiko terkena penyakit yang diakibatkanb oleh makanan jajanan yang berbahaya

(b) Mengamati pengelolaan kantin dan tempat-tempat makanan jajanan di sekolah (Dinkes Pemprov Jawa Barat, 2010).

\section{F. SIMPULAN DAN SARAN}

1. Simpulan

a. Mayoritas pengetahuan siswa tentang jajanan anak sekolah di SD N Cikunir adalah termasuk kategori kurang yaitu 68 orang $(79,1 \%)$.

b. Hasil analisis hubungan antara pengetahuan dan perilaku jajan pada siswa diperoleh $50 \quad(73,5 \%)$ siswa yang pengetahuannya kurang berperilaku jajan sering. Sedangkan 5 orang $(27,8 \%)$ siswa yang pengetahuan kurang termasuk kategori perilaku jajan yang jarang. Hasil uji statistik didapatkan bahwa nilai $\mathrm{P}=0,001$ maka dapat disimpulkan bahwa terdapat hubungan yang signifikan antara 
pengetahuan siswa dengan perilaku jajan.

c. Mayoritas sikap siswa SDN Cikunir tentang jajanan adalah tidak mendukung atau sikap negatif yaitu 64 orang $(74,4 \%)$.

d. Hasil analisis hubungan antara sikap dan perilaku jajan pada siswa diperoleh $14(63,6 \%)$ siswa yang bersikap mendukung (positif) termasuk kategori jarang jajan sedangkan $17(26,6 \%)$ siswa yang memiliki sikap mendukung (positif) termasuk kategori sering jajan.. Hasil uji statistik didapatkan bahwa nilai $\mathrm{P}$ $=0,004$ maka dapat disimpulkan bahwa terdapat hubungan yang signifikan antara sikap siswa dengan perilaku jajan.

e. Mayoritas siswa di SD N Cikunir 59 orang $(68,6 \%)$ tidak memiliki kebiasaan membawa bekal makanan dari rumah ke sekolah.

f. Hasil analisis hubungan antara kebiasaan membawa bekal dengan perilaku jajan adalah siswa yang memiliki kebiasaan membawa bekal $74,1 \%$ jarang jajan sedangkan $18,6 \%$ siswa yang membawa bekal termasuk kategori sering jajan.. Hasil uji statistik didapatkan bahwa nilai $\mathrm{P}=$ 0,000 maka dapat disimpulkan bahwa terdapat hubungan yang signifikan antara kebiasaaan membawa bekal dengan perilaku jajan.

g. Mayoritas siswa menyatakan mendapat dukungan dari guru berupa pemberian informasi dan larangan bahaya jajan sembarangan.

h. Hasil analisis hubungan antara dukungan guru dengan perilaku jajan adalah siswa yang mendapatkan dukungan positif dari guru 45,7\% jarang berperilaku Jajan sedangkan $25 \%$ siswa yang mendapatkan dukungan dari guru termasuk kategori sering jajan. Hasil uji statistik didapatkan bahwa nilai $\mathrm{P}=0,071$ maka dapat disimpulkan bahwa tidak terdapat hubungan antara kebiasaaan dukungan guru dengan perilaku jajan.

2. Saran

a. Bagi siswa

Diharapkan dapat meningkatkan wawasan tentang bahaya jajanan anak sekolah sembarangan melalui berbagai upaya pencarian informasi seperti penyuluhan, informasi di surat kabar, televisi serta internet.

b. Bagi sekolah

Diharapkan dapat merancang kegiatan pencegahan resiko jajanan anak sekolah melalui pemberian informasi tentang bahaya jajanan anak sekolah serta perancangan aturan pengaturan dan pembinaan pedagang di sekitar sekolah.

c. Bagi petugas kesehatan

$$
\begin{aligned}
& \text { Petugas diharapkan dapat } \\
& \text { melaksanakan penyuluhan secara } \\
& \text { berkesinambungan serta melakukan } \\
& \text { pembinaan pada penjaja jajanan anak } \\
& \text { sekolah. }
\end{aligned}
$$

\section{G. DAFTAR PUSTAKA}

Direktorat Jendral Pembinaan Kesehatan Masyarakat Direktorat Bina Gizi Masyarakat Depkes RI. Pedoman pengelolaan dan penyehatan makanan warung sekolah. Jakarta 1994.

Notoatmodjo, S. 2002. Metodologi Penelitian Kesehatan. Edisi revisi. Jakarta: PT Rineka Cipta

Notoatmodjo, S. 2003. Ilmu Kesehatan Masyarakat Prinsip-Prinsip Dasar. PT Rineka Cipta. Jakarta: 205

A.Wawan \&Dewi M, 2011, Teori dan Pengukuran Pengetahuan Sikap dan Perilaku Manusia, Yogyakarta : Muha Medika

Azwar Saifuddin, 2011, Sikap Manusia Teori dan Pengukurannya: Pustaka Pelajar

Andhika Eka Putra, 2009, Gambaran Kebiasaan Jajan Siswa di Sekolah, Semarang 
Dinas Provinsi Jawa Barat,2006, Buku Pedoman Pemilihan Makanan Yang Baik, Bandung

Dinas Provinsi Jawa Barat,2010, Petunjuk Teknis Perilaku Hidup Bersih Dan Sehat (PHBS) Tatanan Sekolah, Bandung

Ditjen PP dan PL Kemenkes, 2013, Modul Pelatihan Fasilitator Peningkatan Hygiene Sanitasi Pangan di Sekolah, Jakarta

Fitriani Sinta, 2011, Promosi Kesehatan, Tasikmalaya: Graha Ilmu

Kepmenkes RI No. 585/menkes/SK/V/2007, Tentang Pedoman Promosi Kesehatan Puskesmas, Jakarta

Kepmenkes RI No. 942/menkes/SK/VII/2003, Tentang Pedoman Persyaratan Hygiene Sanitasi Makanan jajanan, Jakarta

Kemenkes RI, 2014, Buku Pedoman Gizi Seimbang, jakarta

Notoatmodjo Soekidjo, 2013, Promosi Kesehatan Teori \& Aplikasi : PT Rineka Cipta

Notoatmodjo Soekidjo, 2012, Metodologi Penelitian Kesehatan: PT Rineka Cipta

Rina Nuzulia Fitri, 2007, Persepsi Ortu dan Guru terhadap Keamanan Pangan Jajanan Anak Sekolah Dasar di Kota Bogor, Bogor

Safriana, 2012, Perilaku Memilih Jajanan pada Siswa Sekolah Dasar di SDN Garot Kecamatan Darul Imarah Kabupaten Aceh Besar Tahun 2012, Aceh

Sudarmawan, 2012, Hubungan antara Pengetahuan dan Sikap mengenai Pemilihan Jajanan dengan Perilaku Anak Memilih Jajanan di SDN Sambikerep II/ 480 Surabaya, Surabaya 